$\xi_{p}$

\title{
The Impact of Noyyal River Basin on the Quality of Ground Water in Tiruppur District - A Study
}

\author{
K. Ravichandran ${ }^{1}$ Dr. R. Sundararajan ${ }^{2}$ Dr. N. Balasundaram ${ }^{3}$ Dr. T. Senthil Vadivel $^{4}$ \\ 1Research scholar, Department of Civil Engineering, Karpagam Academy of Higher Education, \\ Email.id: drrsundararajan52@gmail.com \\ 2Registrar, Department of Civil Engineering, Karpagam Academy of Higher Education, Coimbatore-641021, Email.id: \\ drrsundararajan52@gmail.com \\ 3Professor and HOD, Department of Civil Engineering, Karpagam Academy of Higher Education, Coimbatore-641021, Tamilnadu. \\ Email.id: balasundaram.n@kahedu.edu.in \\ 4Professor \& Head, Department of Civil Engineering, School of Engineering \& Technology, Adamas University, Kolkata - 700126. West \\ Bengal. Email: tsnsenthu@ rediffmail.com
}

\begin{abstract}
The textile dyeing units operating in Tiruppur have provided Zero Liquid Discharge (ZLD) plants and the system has been in operation for the past ten years. Data on the quality of ground and surface water available with various government agencies such as Public Works Department, Tamil Nadu Pollution Control Board and Central Ground Water Board for the past ten years were collected for the study. Visual MODFLOW, a mathematical Model was used as a tool in the study for analysing the migration of contaminants in the ground water. The parameter, Total Dissolved solids (TDS) was used to represent the contamination level in the ground water. The study area, covering the cluster of industries upstream and downstream of Tiruppur Corporation was selected, and using the data for the period from 2008 to 2017 , the Model was validated. The validated Model was used to make prediction of ground water quality for the next ten years under different scenario.
\end{abstract}

Keywords: Ground water quality. MODFLOW, Noyyal River, Zero Liquid Discharge

\section{Introduction}

Noyyal River originates at Velliangiri hills of in the Western Ghats and flows through Coimbatore, Tiruppur, Erode and Karur Districts and confluences with River Cauvery at Noyyal village of Karur District. The Noyyal River and the Orathupalayam Dam located at downstream side of Tiruppur city is notorious for industrial pollution from the cluster of Textile dyeing units operating in and around Tiruppur Town. The indiscriminate discharge of effluents from the textile dyeing units has polluted the River basin and the Orathupalayam Dam and affected the quality of ground water in the area. The Hon'ble High court of Madras and Hon'ble Supreme court of India, in a Public Interest Litigation petition filed by the affected farmers' association, have passed several orders including payment of compensation to the affected farmers based on the contamination level of ground water, implementation of ZLD technology by the dyeing units either collectively or individually and closure of industrial units not complying with the standards. Presently the dyeing units have installed ZLD system collectively in 18 CETPs and individually in 48 units, and no unit is allowed to operate without ZLD plant. The ZLD plants installed by these units have been in operation for more than ten years. The quality of ground water around Tiruppur available right now and that of the future was predicted under different scenarios, using Visual Modflow.

\section{Study Area}

The area selected for study mainly falls in Tiruppur district of Tamil Nadu covering 7.5KM distance on either side of the River to a total distance of

40KM. (Size-L $=40 \mathrm{KM}$ and width= 15KM). The Latitude and Longitude of the area are 77o14'"00"E to' 77o 35'14" E and11001'48'N to '11o 10'00" N respectively.

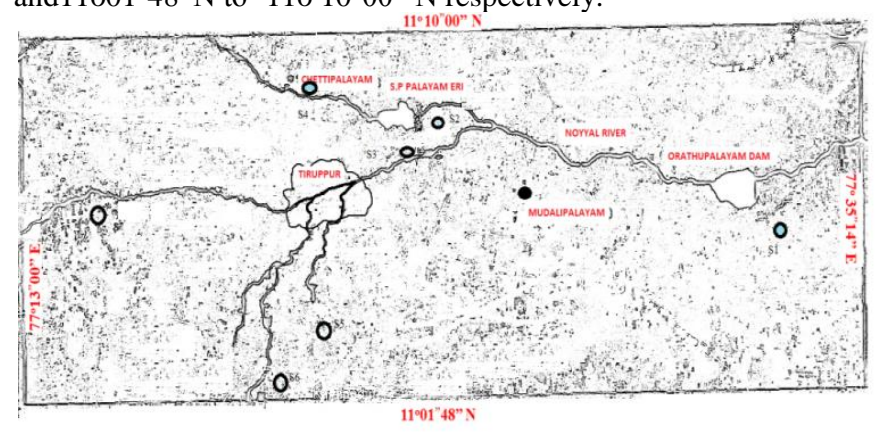

Fig. 1: Noyyal River Base Map 
The following seven monitoring was selected covering upstream and downstream side of the cluster and other important points.

\section{Data Collection}

\subsection{Primary Data}

The following seven monitoring wells were selected covering the upstream and downstream side of the Tiruppur dyeing industrial cluster. Samples were collected and analysed for the year 2015, 2016 and 2017 , and base line water quality was created.

The following are the locations of wells.

1. S1-Dugwell adjacent to Orathupalayam Dam $(20 \mathrm{~km} \mathrm{~d} / \mathrm{s}) 11^{\circ} 05^{\prime} 49^{\prime \prime} \mathrm{N}: 77^{\circ} 32^{\prime} 46^{\prime \prime} \mathrm{E}$

2. S2-Dugwell at S.Periyapalayam $(6 \mathrm{~km} \mathrm{~d} / \mathrm{s}) .11^{\circ} 08^{\prime} 00^{\prime \prime} \mathrm{N}: 77^{\circ} 24^{\prime} 15^{\prime \prime} \mathrm{E}$

3. S3-Murugasamy garden bore well $(6 \mathrm{~km} \mathrm{~d} / \mathrm{s}) .11^{\circ} 07^{\prime} 20^{\prime \prime} \mathrm{N}: 77^{\circ} 23^{\prime} 58^{\prime \prime} \mathrm{E}$

4. S4-Boopathy's RasiThottam open well $11^{\circ} 08^{\prime} 35^{\prime \prime} \mathrm{N}: 77^{\circ} 20^{\prime} 30^{\prime \prime} \mathrm{E}$

5. S5-Corporation bore well - Veerapandy bus stop. $11^{\circ} 03^{\prime} 47^{\prime \prime} \mathrm{N}: 77^{\circ} 21^{\prime} 06^{\prime \prime} \mathrm{E}$

6. S6-Rajamani bore well $11^{\circ} 02$ ' 00 " N:77 ${ }^{\circ} 19^{\prime} 28^{\prime \prime} \mathrm{E}$.

7. S7-Muthurathinam open well $11^{\circ} 06^{\prime} 23^{\prime \prime} \mathrm{N}: 77^{\circ} 15^{\prime} 57^{\prime \prime} \mathrm{E}$.

\subsection{Secondary Data}

\begin{tabular}{|l|l|l|}
\hline 1 & $\begin{array}{l}\text { PWD- Groundwater } \\
\text { Division, Chennai }\end{array}$ & $\begin{array}{l}\text { i). Tiruppur District groundwater } \\
\text { profile } \\
\text { ii). Monitoring well data }\end{array}$ \\
\hline 2 & $\begin{array}{l}\text { PWD - Irrigation division } \\
\text { Erode }\end{array}$ & $\begin{array}{l}\text { Noyyal River Water flow and } \\
\text { quality }\end{array}$ \\
\hline 3 & $\begin{array}{l}\text { Loss of Ecology (P\&PC) } \\
\text { Authority }\end{array}$ & $\begin{array}{l}\text { Report on assessment of loss of } \\
\text { ecology and environment in } \\
\text { Noyyal River basin }\end{array}$ \\
\hline 4 & $\begin{array}{l}\text { Central Ground Water Board, } \\
\text { Chennai }\end{array}$ & $\begin{array}{l}\text { i). Well water quality and level } \\
\text { data } \\
\text { ii). Exploratory tube well reports }\end{array}$ \\
\hline 5 & $\begin{array}{l}\text { Regional Meteorological } \\
\text { Department, Chennai }\end{array}$ & $\begin{array}{l}\text { Rainfall data for Tiruppur } \\
\text { district }\end{array}$ \\
\hline 6 & Survey of India, Chennai & $\begin{array}{l}\text { Tiruppur district maps on } \\
\text { drainage, soil, geology, } \\
\text { geomorphology }\end{array}$ \\
\hline 7 & TNPCB, Tiruppur (north) & $\begin{array}{l}\text { CETPs, ETPs, STPs \& River } \\
\text { water analysis reports }\end{array}$ \\
\hline
\end{tabular}

\section{Objective of the Study}

- To carry out a detailed assessment of the quality of existing groundwater on Noyyal river basin, which is highly polluted by industrial discharge.

- To predict the groundwater quality in this area over a period of next 10 years by using VISUAL MODFLOW model under various scenarios.

- To suggest remedial measures to improve the groundwater quality in this area.

\section{Methodology}

The study was carried out using Visual MODFLOW. Visual MODFLOW provided professional 3D groundwater flow and contaminated transport modeling using MODFLOW, MODPATH and MT3D. MODFLOW simulated groundwater flow within the aquifer using block-centered finite-difference approach. MODPATH tracked particle from one cell to the next until the particle reaches a boundary. MT3D was a Comprehensive three dimensional numerical model for simulating solute transport in complex hydro geologic settings.

The study area was divided into $200 \mathrm{~m}$ x $200 \mathrm{~m}$ grid, and 15000 cells were created. The input parameters such as ground level, aquifer characters, initial ground water level (2008 data from State ground water Board), Rainfall and boundary conditions were fed into the Model. The Ground water level computed by the Model for the year 2017 was compared with the values observed in the observation well and the Model was validated. Total Dissolved solids (TDS) in ground water were selected as particle and the initial concentration data of the year 2008 was fed into the Model, and the recharge concentration details were fed into the Model. The TDS concentration level computed by the Model for the year 2017 was compared with the values observed in the observation well, and the Model was validated. By using the validated Model prediction of TDS concentration in the ground water was predicted under different scenario for the next ten years.

\section{Pollution Load on the River System}

At present about 400 textile dying units are connected with common effluent plant treatment system (CETPs), and 50 dyeing units have provided individual treatment system (IETPs) with ZLD concept. There are several issues connected with the operation and maintenance of ZLD plants such as high capital and operational cost, requirement of skilled man power for the operation and problems associated with the disposal of a huge quantity of hazardous waste. For the purpose of the study it is assumed that about $10 \%$ of the pollution load generated from the dyeing units is left untreated and reaches the ground water either directly or indirectly.

Table 1: .Effluent generation capacity of dyeing units in Tiruppur.

\begin{tabular}{|l|l|l|l|}
\hline Sl.No & Name Of The Cetp & Design Capacity(Kld) & Operation Level(Kld) \\
\hline 1 & Andipalayam Cetp & 2730 & 820 \\
\hline 2 & Angeripalayam Cetp & 10000 & 4000 \\
\hline 3 & Chinnakarai Cetp & 8000 & 4000 \\
\hline 4 & Eastern Cetp & 6000 & 4500 \\
\hline 5 & Kallikadu Cetp & 3000 & 1500 \\
\hline 6 & Kaspalayam Cetp & 4400 & 3520 \\
\hline 7 & Mangalam Cetp & 3880 & 1164 \\
\hline 8 & Mannarai Cetp & 4165 & 2400 \\
\hline
\end{tabular}




\begin{tabular}{|c|c|c|c|}
\hline 9 & Park Cetp & 2500 & 2250 \\
\hline 10 & Rayapuram Cetp & 5500 & 2750 \\
\hline 11 & Sirupooluvapatty Cetp & 5000 & 2500 \\
\hline 12 & S.Periyapalayam Cetp & 1200 & 180 \\
\hline 13 & Tiruppur Murugampalayam Cetp & 9460 & 4730 \\
\hline 14 & Veerapandy Cetp & 11929 & 7160 \\
\hline 15 & Vettuvapalayam Cetp & 1300 & 195 \\
\hline 16 & Arulpuram Cetp & 5500 & 4950 \\
\hline 17 & Karaipudhur Cetp & 4500 & 3150 \\
\hline 18 & Kunnangalpalayam Cetp & 4500 & 2250 \\
\hline \multirow[t]{2}{*}{19} & Ietp & 25000 & 25000 \\
\hline & & Total & 77019 Kld \\
\hline
\end{tabular}

value of the raw effluent is about $6000 \mathrm{mg} / \mathrm{l}$, assuming that,with $10 \%$ TDS going into River system, the estimated pollution load is 46.2 Tonnes//day. $(=0.1 \quad$ x $\quad 6 g / 1 \quad$ x 77019 x $1000 \quad$ kg=46.2 Tonnes/day).

\section{Prediction Scenario}

After validation of the Model Groundwater quality (TDS) was predicted for the next 10 years for the following scenarios:

1. If the present scenario continued. In this it was assumed $10 \%$ of effluent generated would be discharged into the River system.

2. If the pollution was doubled with $20 \%$ of effluent discharged into the River system. This might be under the condition that production was doubled due to industrial growth or more accidental discharge was made into the River system.

3. If the groundwater recharge was increased by 1.5 times and ZLD by the industries. Presently during flow in the River the water is not stored in the dam. If water was stored in the Dam and more water storage structures were created there, the recharge would

\section{Results and Discussion}

\subsection{Noyyal River Flow}

The PWD Irrigation Department is collecting samples of daily inflow and outflow, and the TDS value in the dam and the average values are given in the table and in the chart. The monthly average flow in the River at the downstream side of Tiruppur from the year 2011 to 2017 varies between 25 and 60 cusecs except for a month or two. Further, the River is always in dry condition on the upstream side and the flow is recorded only during rain. The flow recorded in the dam is mainly contribution from domestic sewage from Tiruppur corporation area and from dyeing and other garment industries, which are using considerable quantity of ground water and discharging effluents into the River system either directly or indirectly. The average value of TDS recorded during the study period varies from 2500 $\mathrm{mg} / \mathrm{l}$ to $3000 \mathrm{mg} / \mathrm{l}$, and it reveals that there is a contribution of TDS from the dyeing units even though it is claimed that they have installed and are operating ZLD plants and the assumption of $10 \%$ discharge of pollutants into the River system is a valid one.

Table 2: Average flow recorded in Noyyal River at Orathupalayam dam

\begin{tabular}{|c|c|c|c|c|c|c|c|}
\hline Year & & & & & & & \\
\hline Month & 2011 & 2012 & 2013 & 2014 & 2015 & 2016 & 2017 \\
\hline Jan & 122 & 161 & 28 & 40 & 83 & 82 & 23 \\
\hline Feb & 64 & 130 & 42 & 34 & 40 & 45 & 26 \\
\hline Apr & 95 & 59 & 20 & 19 & 71 & 33 & 4 \\
\hline May & 80 & 58 & 19 & 47 & 154 & 44 & 28 \\
\hline Jun & 156 & 34 & 21 & 31 & 194 & 41 & 30 \\
\hline Sep & 92 & 25 & 20 & 82 & 49 & 35 & 208 \\
\hline Oct & 132 & 62 & 105 & 158 & 87 & 38 & 76 \\
\hline Nov & 555 & 51 & 39 & 103 & 153 & 47 & 72 \\
\hline Dec & 330 & 35 & 42 & 85 & 137 & 34 & 71 \\
\hline
\end{tabular}




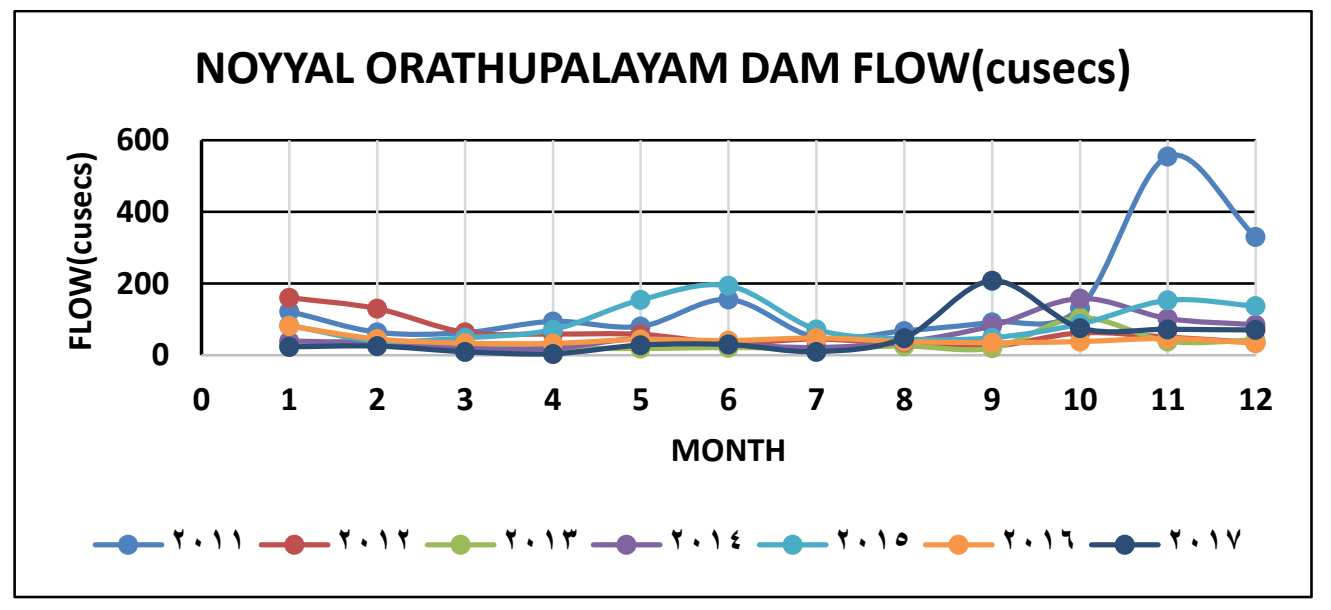

Fig. 2: Average flow in Orathupalayam dam

Table 3: Average TDS recorded in Noyyal River at Orathupalayam dam

\begin{tabular}{|c|c|c|c|c|c|c|c|}
\hline Year & & & & & & & \\
\hline Month & 2011 & 2012 & 2013 & 2014 & 2015 & 2016 & 2017 \\
\hline FEB & 4171 & 2697 & 2521 & 2629 & 3379 & 3472 & 2665 \\
\hline APR & 2767 & 2723 & 2630 & 2990 & 2740 & 3653 & 3004 \\
\hline MAY & 2752 & 2519 & 2616 & 2845 & 2461 & 3423 & 2852 \\
\hline JUN & 2263 & 2610 & 2630 & 2730 & 2397 & 3435 & 2826 \\
\hline SEP & 2300 & 2417 & 2610 & 2760 & 2693 & 2535 & 1893 \\
\hline OCT & 2316 & 2365 & 2426 & 2468 & 2129 & 2506 & 2503 \\
\hline NOV & 1947 & 2773 & 2627 & 2847 & 2170 & 2532 & 2571 \\
\hline DEC & 2390 & 3019 & 2652 & 3148 & 2523 & 2900 & 2758 \\
\hline
\end{tabular}

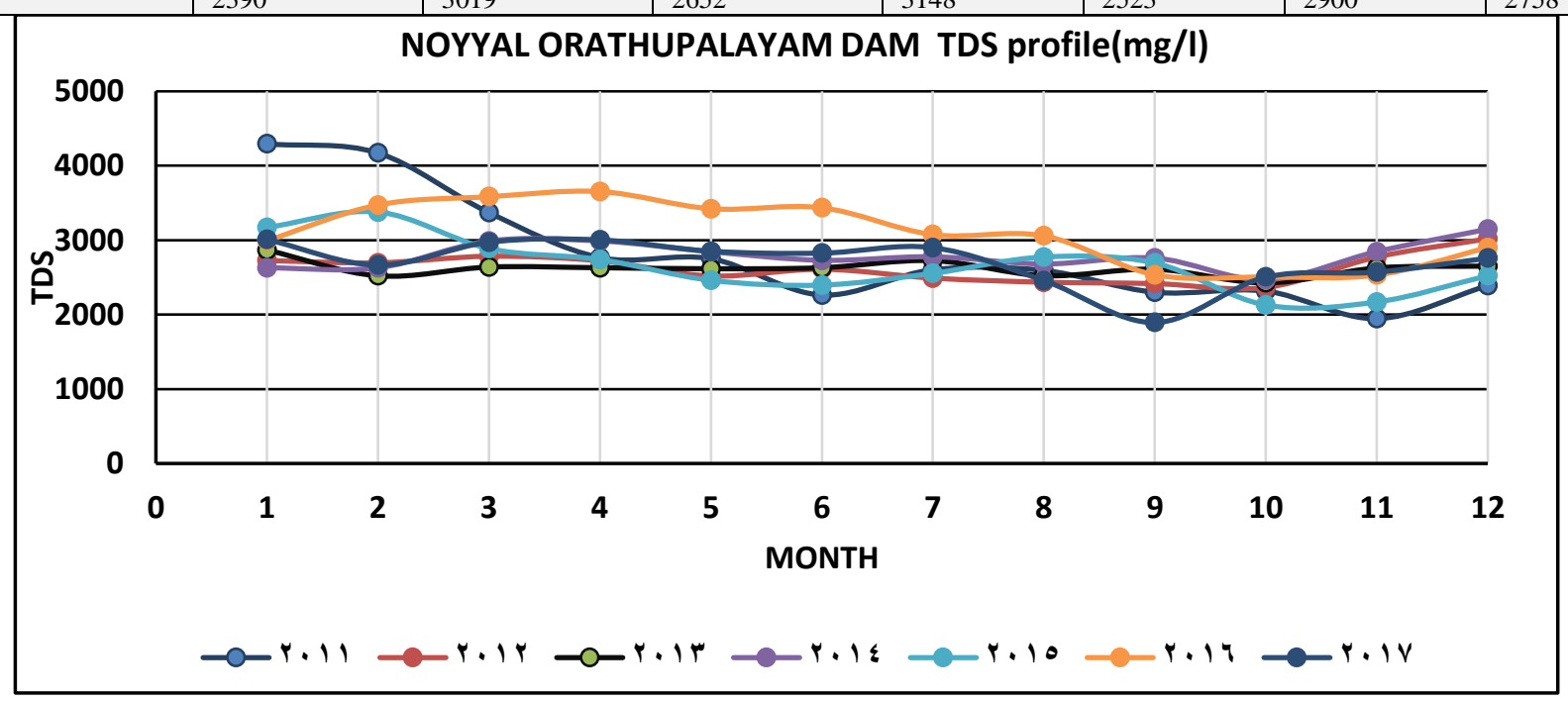

Fig. 3: Average TDS in Orathupalayam dam

8.2. Ground Water Quality in the Monitoring Wells.

Even though the study was conducted mainly for TDS value, the other parameters Chloride, Sulphate and Hardness were analysed during 2018, and the report of analysis (ROA) is given in table 4.2 and the said parameters follow the same pattern of TDS.
There was no organic pollution load in the monitoring wells and it was evident from the very low values of Total Suspended Solids, BOD, and COD observed in all the seven monitoring wells.

Table 4: Water quality in monitoring wells

\begin{tabular}{|l|l|l|l|l|l|l|l|l|}
\hline S. No & Parameters & S-1 & S-2 & S-3 & S-4 & S-5 & S-6 & S-7 \\
\hline
\end{tabular}




\begin{tabular}{|c|c|c|c|c|c|c|c|c|}
\hline 1 & $\mathrm{pH}$ & 7.56 & 7.45 & 7.89 & 7.57 & 8.18 & 7.32 & 7.38 \\
\hline 2 & Total Suspended olids(mg/l) & 4 & 4 & 4 & 4 & 4 & 4 & 4 \\
\hline 3 & Total Dissolved Solids(mg/l) & 3150 & 2500 & 3660 & 4816 & 2192 & 3612 & 5316 \\
\hline 4 & Chloride (as Cl) (mg/l) & 1450 & 1210 & 1322 & 1923 & 673 & 1346 & 2067 \\
\hline 5 & Sulphate $\left(\right.$ as $\left.\mathrm{SO}_{4}\right)(\mathrm{mg} / \mathrm{l})$ & 650 & 533 & 725 & 947 & 475 & 825 & 1190 \\
\hline 6 & $\mathrm{COD}(\mathrm{mg} / \mathrm{l})$ & 35 & 61 & 41 & 32 & 24 & 203 & 97 \\
\hline 7 & BOD 3 days at $27^{\circ} \mathrm{c}(\mathrm{mg} / \mathrm{l})$ & 5 & 6 & 3 & 2 & 2 & 18 & 8 \\
\hline 8 & Oil \& Grease $(\mathrm{mg} / \mathrm{l})$ & $<1$ & $<1$ & $<1$ & $<1$ & $<1$ & $<1$ & $<1$ \\
\hline 9 & AmmonicalNitrogen(mg/l) & $<5$ & $<5$ & $<5$ & $<5$ & $<5$ & $<5$ & $<5$ \\
\hline 10 & Phenolic Compounds(mg/l) & $<0.0005$ & $<0.0005$ & $<0.0005$ & $<0.0005$ & $<0.0005$ & $<0.0005$ & $<0.0005$ \\
\hline 11 & Total Hardness $(\mathrm{mg} / \mathrm{l})$ & 1215 & 710 & 600 & 1480 & 1880 & 980 & 1860 \\
\hline 12 & $\%$ Sodium & 53 & 52 & 82 & 61 & 50 & 59 & 64 \\
\hline
\end{tabular}

\subsection{Tds Profile in Monitoring Wells in Scenario S1, S2, And S3}

S1-Dugwell adjacent to Orathupalayam Dam (20km d/s) There was a drastic reduction in the values of TDS during 2008 2017. Water storage in the Orathupalayam Dam has been completely stopped from the year 2004, and there is a gradual improvement in the ground water quality, and a drastic reduction in the TDS value is observed around the dam area. Further, the ground water quality almost follows the same pattern for the next ten years in scenario -1 and scenario-2, as there is no water storage proposed in the dam in the near future. Further, if rain water is stored in the dam for improving recharge by making bypass arrangement for polluted water, it shows that there is improvement in the ground water quality in the adjoining areas.

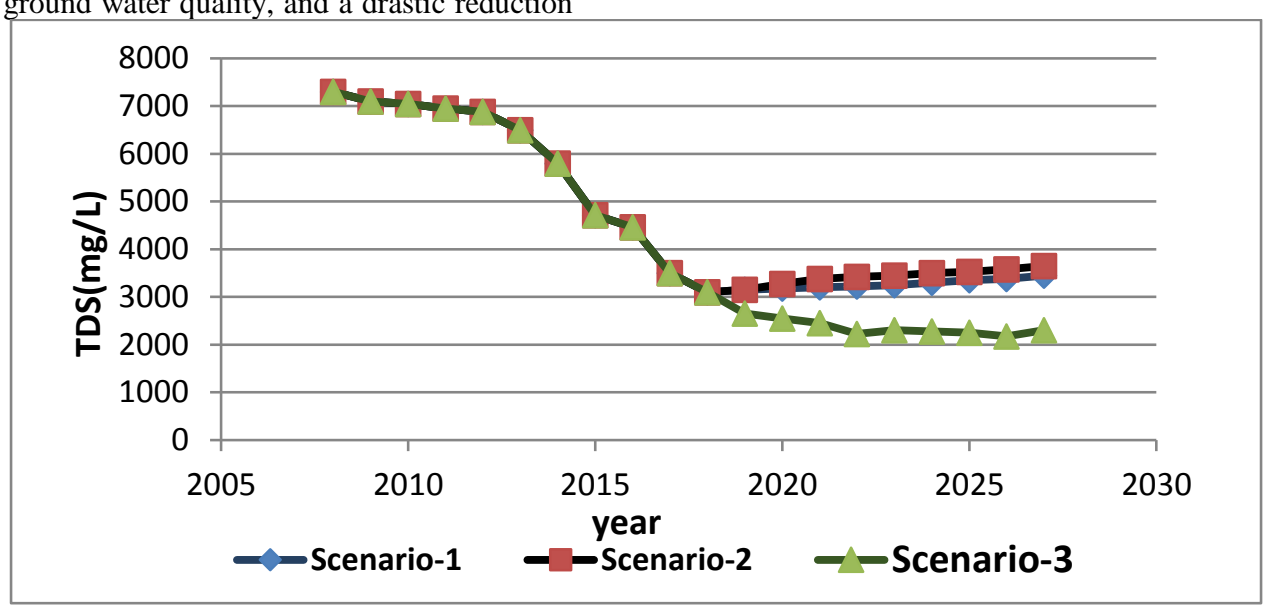

Fig. 4: TDS profile in dug well adjacent to Orathupalayam dam

\subsubsection{S2 And S3-Wells Located $6 \mathrm{~km} \mathrm{D} / \mathrm{S}$ Of Industrial Cluster}

The S2-Dugwell at S.Periyapalayam is located adjacent to S.Periyapalayam Eri and S3-Murugasamy garden bore well is located adjacent to the River and both wells are about $6 \mathrm{~km}$ downstream of industrial cluster.
Both wells follow the same pattern under scenario -1 and scenario-2, and there is a slight increase in the TDS value, which reveals an increase in the contamination level. Improving the recharge to 1.5 times by making suitable water storage structures in the River basin reduces the contamination level in the ground water under scenario-3. 


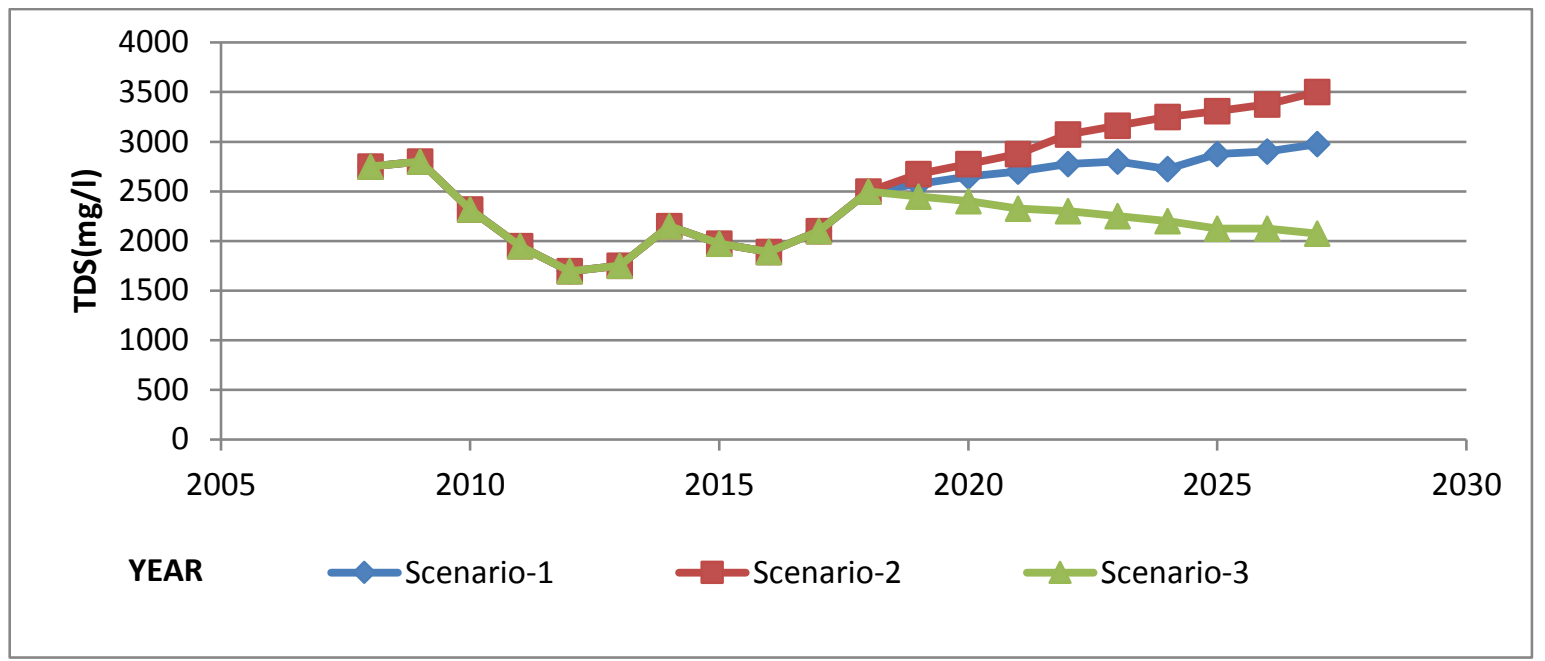

Fig. 5: S2 TDS profile in dug well adj to S.Periyapalayam

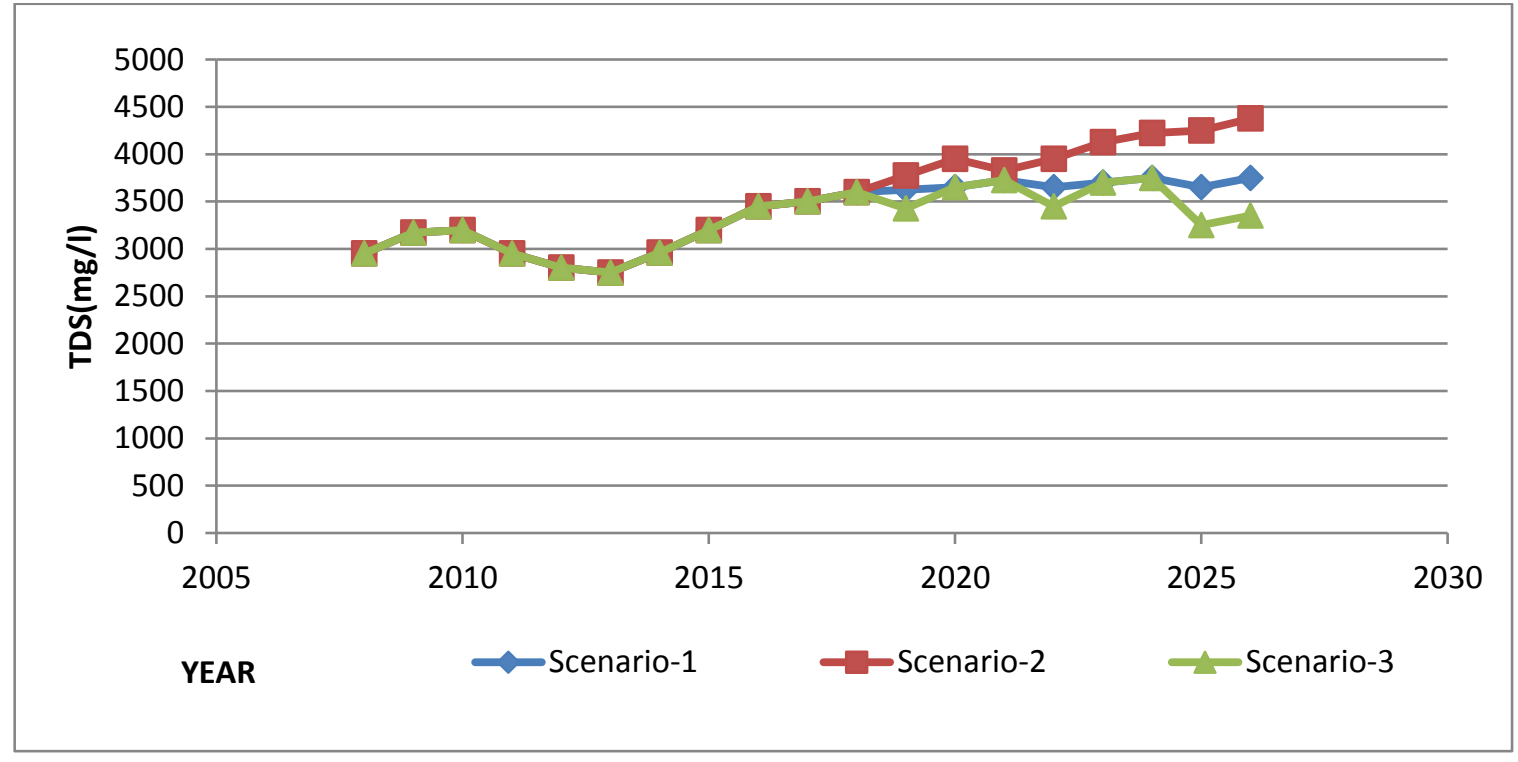

Fig. 6: S3.TDS profile in Murugasamy garden bore well.

\subsubsection{S4, S5 And S6-Tds Trend In Wells In The Textile Dyeing Cluster.}

These wells are located within Tiruppur Corporation area and within the dyeing cluster area. 


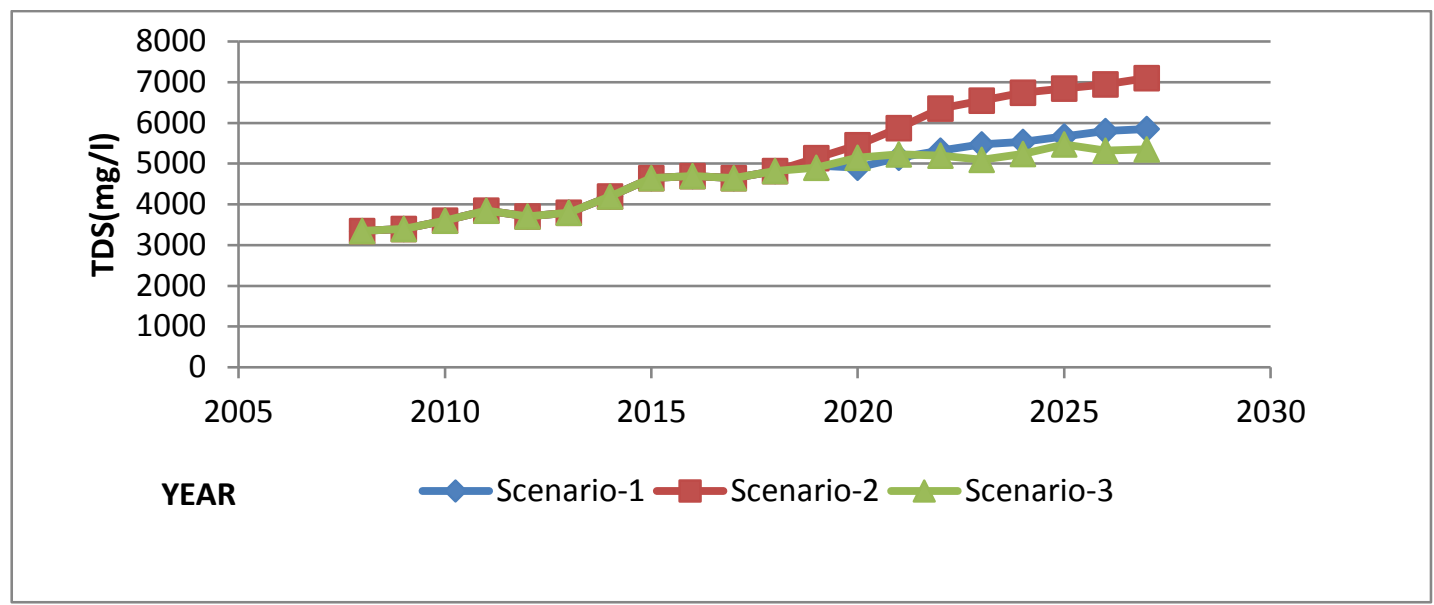

Fig. 7 : S4-Boopathy's RrasiThottam open well

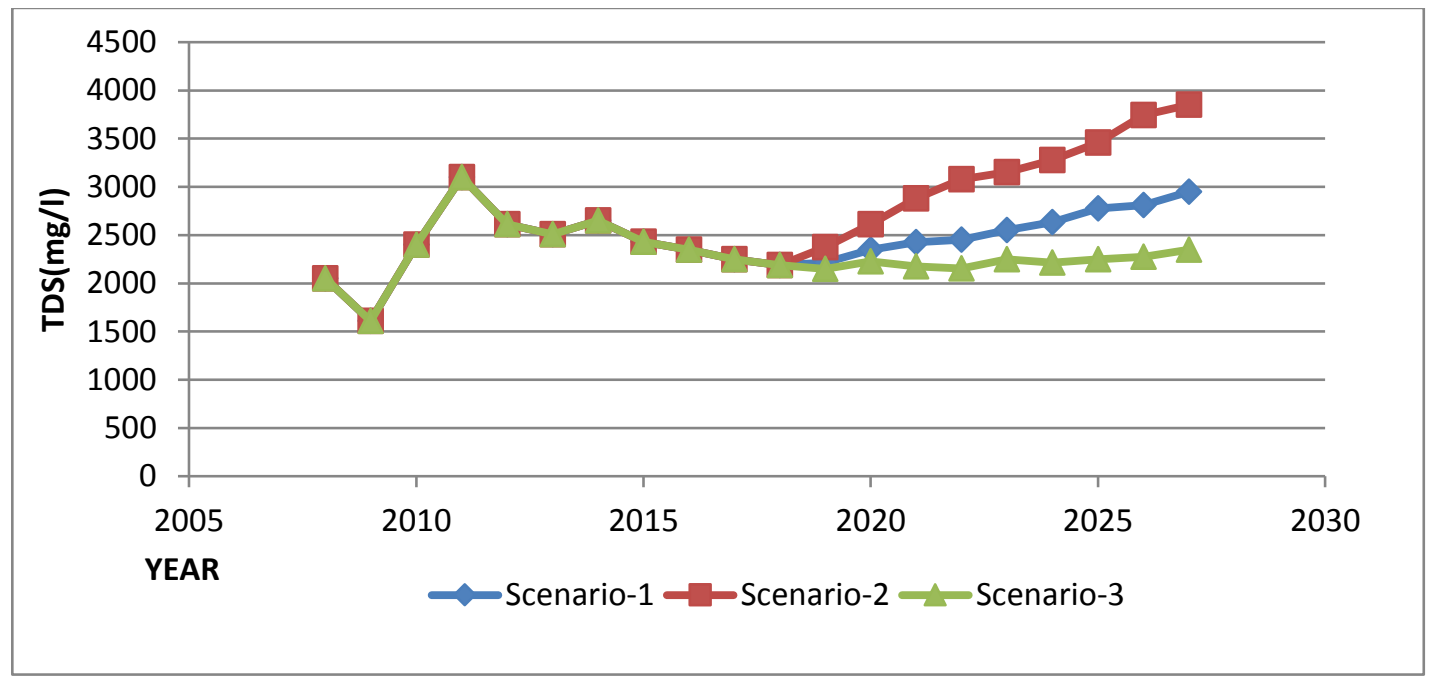

Fig. 8: S5-Corporation bore well - Veerapandy bus stop

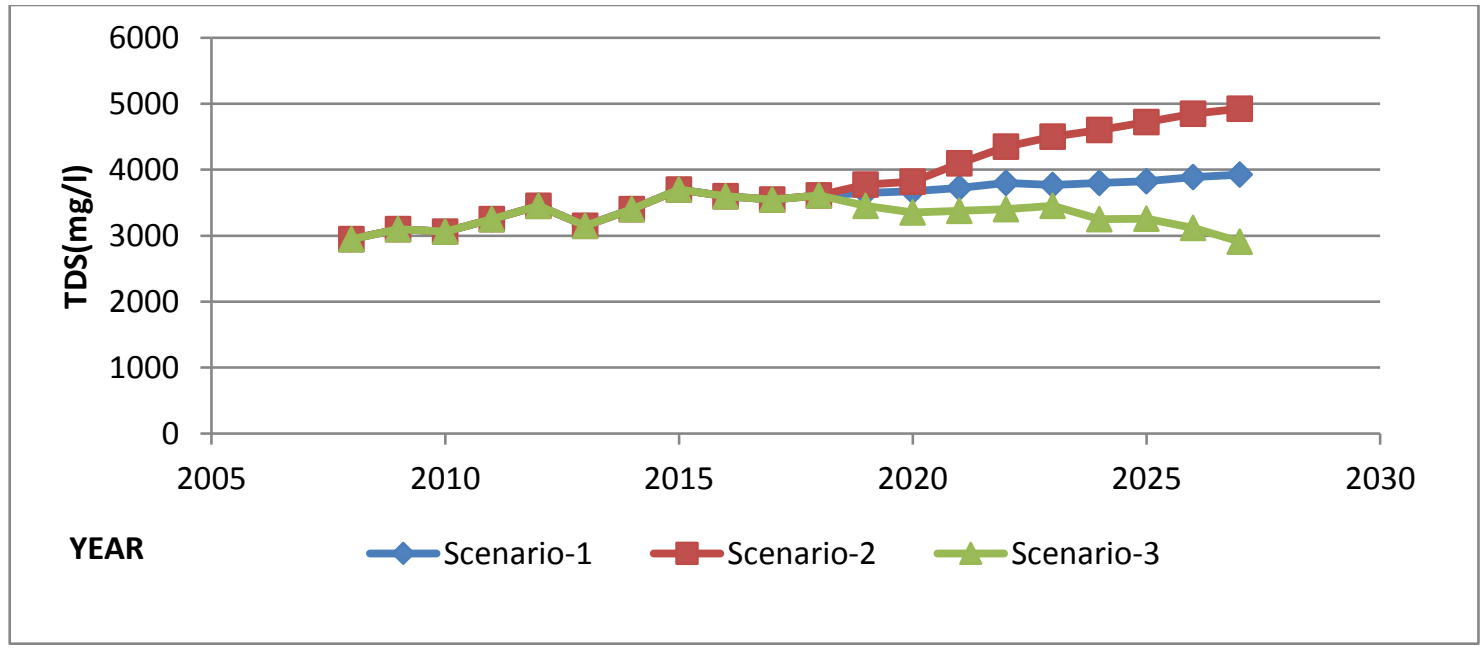

Fig. 9: S6-Rajamani bore well 
In all these wells during 2008-2017, there was a gradual increase in contamination level within the cluster area, whereas the contamination level gradually reduced in other areas away from the cluster, especially in the dam area. This might be due to a strict implementation of the operation of ZLD plants by the enforcement agencies. The same trend would continue in future also in scenario- 1 and scenario- 2 .

\section{Conclusions}

After the implementation of ZLD technology by dyeing units there has been improvement of ground water quality in the study area. There is a considerable reduction in TDS value around the dam area, whereas the contaminant level increases within the cluster area. Providing adequate recharge structures in the River and for storing rain water in the Dam and S.Periyapalayam Eri will improve the recharge and the ground water quality.

\section{References}

[1] Arumugam.K, A.Rajesh Kumar, K.Elangovan, S.Loganathan and D Ambiga5,2015, "Geochemical Process Controlling Groundwater Quality in Avinashi and Tirupur Region, Tamil Nadu, India", International Journal of Applied Environmental Science, Volume 10,Number 1, pp. 1-13.

[2] Brema.J , G. Prince Arulraj ,2012, "Identification of sites suitable for artificial Recharging And Groundwater Flow Modeling in Noyyal River Basin, Tamil Nadu, India. Brema and Arulraj / OIDA International Journal of Sustainable Development 03: 08.

[3] Ganesh Babu.O, R. Saravanan, M.C.Sashikkumar and S. Pitchaikani, "Assessment of Groundwater Vulnerability to Pollution Using Modflow" The Asian Review of Civil Engineering, Vol. 4 No. 1, 2015, pp.20-27.

[4] Geethaselvarani.A, K. Elangovan and C. Siva kumar, 2016 "Evaluation of Groundwater Potential Zones Using Electrical Resistivity and GIS in Noyyal River Basin, Tamil Nadu, Journal Geological Society of India, Vol.87, pp.573-582.

[5] GeethaSelvarani.A, G. Maheswaran \& K. Elangovan, 2015 , "Identification of Artificial Recharge Sites for Noyyal River Basin Using GIS and Remote Sensing", J Indian Soc Remote Sens ,12524-015-0542-5.

[6] Loss of ecology (prevention and payments of compensation) authority for the state of Tamil Nadu report and award for tiruppur cluster of textile industries in noyyal river basin dt December 17th 2004.

[7] Report on Assessment of Ground Water in the industrial cluster of Tiruppur published by Central Ground Water Board Chennai Aug 2016.

[8] Tamil Nadu Pollution Control Board Noyyal River Report of Analysis.

[9] Shanthi.P, Dr. T. Meenambal, N. Balasundaram, 2012, “ Physico Chemical Analysis of Ground Water Near Municipal Solid Waste Dumping Sites In Coimbatore City", IRACST - Engineering Science and Technology: An International Journal (ESTIJ), ISSN: 2250-3498, Vol.2, No. 5.

[10] Saravanan.R , R. Balamurugan , M.S. Karthikeyan , R. Rajkumar, N.G. Anuthaman , A.Navaneetha Gopalakrishnan , 2011, "Groundwater modeling and demarcation of groundwater protection zones for Tirupur Basin e A case study" ,Journal of Hydro-environment Research,197 -212.

[11] ShashiPrabha, Manish Kumar, Alok Kumar, Pallavi Das, AL. Ramanathan, 2013, “ Impact assessment of textile effluent on groundwater quality in the vicinity of Tirupur industrial area, southern India", Environ Earth Sci 70, pp.3015-3022. 